\title{
METODE PENDIDIKAN KARAKTER NABI MUHAMMAD SAW DI MADRASAH
}

\author{
Farhat Abdullah
}

\section{A. Abstraksi}

Pendidikan Karakter dapat dimaknai dengan pendidikan nilai, budi pekerti, moral, dan watak, yang bertujuan untuk memberikan keputusan baik buruk, memelihara apa yang baik,dan mewujudkan kebaikan dalam kehidupan sehari-hari dengan sepenuh hati.

Nabi Muhammad Sallahu 'Alaihi Wa Sallam adalah utusan Allah Subhanahu Wa Ta'ala sebagai penyempurna akhlak dan pendidik. Beliau mendapat didikan langsung dari Tuhan-Nya sehingga memiliki akhlak yang paling sempurna di muka bumi ini, sehingga menjadi manusia yang agung dengan kesaksian Allah yang diabadikan dalam Firman-Nya:

"Dan sungguh kamu benar-benar berbudi pekerti yang agung"1

Kesaksian yang agung dari Allah tentang Nabi Muhammad Sallahu 'Alaihi Wa Sallam adalah bukti bahwa akhlak Beliau agung dan mulia sejak diciptakannya. Beliau terkenal di antara kaumnya sebagai orang yang jujur dan terpercaya. Sebagai sosok yang agung, Beliau mendapat tugas mulia dari Yang Maha Agung, yaitu memperbaiki dan menyempurnakan akhlak manusia, sebagai mana sabdanya:

\section{"Hanya sanya aku diutus untuk menyempurnakan akhlak manusia"2}

Beliau berhasil melaksanakan amanah besar dengan mengubah masyarakat jahiliyah menjadi masyarakat yang beriman dan beradab, sekaligus mencetak manusia yang berkarakter mulia.

Berbeda dengan kondisi umat jaman kini telah terjadi krisis moral di negeri ini yang mayoritas berpenduduk agama lslam, mulai usia remaja, dewasa bahkan sampai orang tua. Banyak pejabat yang korupsi seakan menjadi budaya yang lumrah dan legal, pengusaha yang zolim, dan pedagang yang curang. Para pemuda yang terlena dan tertipu dengan kenikmatan sesaat yang membawa kesengsaraan seumur hidup, berupa pergaulan bebas sejenis atau beda jenis (LGBT), Narkoba, begal dan tawuran.

Komisi Perlindungan Anak lndonesia (KPAI)3 mencatat kasus tawuran pelajar selama empat tahun terakhir, yakni tercatat ada 102 kejadian tawuran dengan korban meninggal 17 orang. Kemudian sepanjang januari - oktober tahun 2013 meningkat menjadi 229 kasus tawuran antar pelajar SMP dan SMA dengan korban meninggal dunia 19 orang. $^{3}$ 
Semakin terbukanya akses informasi ditambah tekanan dari lingkungan, diyakini menjadi penyebab banyaknya remaja yang melakukan seks bebas prenikah. Saat ini akses terhadap materi pornoaksi sebakin terbuka lebar, misalnya melalui internet atau telefon seluler, ditambah lagi semakin banyak yang memiliki rasa ingin tahu, dan senang mencoba hal yang baru tanpa memikirkan resikonya. Kasus lain yang melibatkan pelajar adalah kasus penyalahgunaan narkotika dan obat terlarang. Menurut data Badan Narkotika Nasional (BNN) ${ }^{4}$, pada tahun 2012 pengguna narkotika dan obat terlarang di lndonesia ada sekitar 4000 orang atau sekitar 2,8 \% dari jumlah penduduk nasional, sekitar $25 \%$ atau sekitar 1000 orang merupakan pecandu narkoba di kalangan pelajar/mahasiswa. Bahkan ironisnya lagi bisnis narkoba di masyarakat dikendalikan dan dikoordinir oleh narapinada narkoba di dalam rumah tahanan atau lembaga pemasyarakatan. Badan Narkotika Nasional telah mensita aset narapinada narkoba senilai Rp. 28 Milyar $^{5}$

\section{B. PEMBAHASAN}

1. Metode

Metode adalah cara teratur yang digunakan untuk melaksanakan suatu pekerjaan agar tercapai sesuai dengan yang dikehendaki; cara kerja yang bersistem untuk memudahkan pelaksanaan suatu kegiatan guna mencapai tujuan yang ditentukan. ${ }^{6}$

Dalam bahasa Arab, istilah metode biasa disebut manhaj. Abu Namira Hasna Al-Jauziyah ${ }^{7}$ menerangkan dari segi bahasa manhaj adalah jalan yang jelas lagi terang, dan digunakan untuk menyebut jalan yang lurus, atau sunnah.

Kata manhaj / minhaj bermakna jalan yang terang atau sunnah disebut dalam Al-Qur'an :

Untuk tiap-tiap umat (antara kalian), Kami berikan aturan dan jalan yang terang (atau sunnah). ${ }^{8}$

Dalam bahasa populer, manhaj sering diartikakan sebagai "paradigma", yaitu seperangkat konsep, rumusan tata laksana dan juga perangkat nilai yang digunakan oleh sekelompok orang atau komunitas sebagai panduan dalam berbuat, berpikir, melangkah, atau dalam menentukan kebijakan. ${ }^{9}$

Manhaj Nabi Muhammad Sallahu 'Alaihi Wa Sallam dalam da'wah secara umum dan dalam pendidikan karakter secara khusus dapat dipahami dalam firman Allah Subhanahu Wa Ta'ala, di antaranya :

"Sungguh Allah telah memberi karunia kepada orang-orang yang beriman, ketika Allah mengutus di antara mereka seorang rasul dari golongan mereka sendiri, yang membacakan kepada mereka ayat-ayat Allah, membersihkan jiwa mereka, dan mengajarkan Al-Kitab dan Al-Hikmah, dan sesungguhnya sebelum kedatangan Nabi mereka benar-benar dalam kesesatan yang nyata" 10 
Ayat ini menjelaskan bahwa Nabi Muhammad Sallahu 'Alaihi Wa Sallam datang sebagai pembersih jiwa, pendidik, guru, dan yang memperbaiki keadaan. Beliau bersungguh-sungguh dalam menjalankan tugasnya dengan mengerahkan segala yang beliau punya, jiwa raga untuk mendidik para sahabat dengan pendidikan paripurna, sehingga upaya itu menghasilkan satu generasi yang terbaik sehingga oleh Allah Subhanahu Wa Ta'ala.

"Kalian adalah umat yang terbaik yang dilahirkan untuk manusia, menyuruh kepada yang ma'ruf dan mencegah kepada yang munkar dan beriman kepada Allah"11

Dengan demikian yang dimaksud dengan metode (manhaj) Nabi Muhammad Sallahu 'Alaihi Wa Sallam adalah jalan terang yang ditempuh oleh Nabi Muhammad Sallahu 'Alaihi Wa Sallam dalam mendidik para sahabat. Metodenya meliputi prinsip dasar pendidikan, sistem pendidikan dan metode pendidikan.

2. Pendidikan Karakter

a. Pengertian Karakter

Abdullah Munir menyebutkan bahwa karakter itu adalah sebuah pola, baik itu pikiran, sikap maupun tidakan yang melekat pada diri seseorang dengan sangat kuat dan sulit dihilangkan. ${ }^{12}$

Bagaimana proses terbentuknya karakter? Fatchul Mu'in menyebutkan, "Karakter dibentuk oleh pengalaman dan pergumulan hidup. Pada akhirnya tatanan dan situasi kehidupanlah yang menentukan terbentuknya karakter masyarakat kita."13

Dalam istilah agama lslam, karakter biasa disebut dengan akhlak. Ibnul Atsir menyeutkan al-khuluqu dan al-khulqu dalam an-Nihayah (2/70), berarti dien, tabiat, dan sifat. Hakikatnya adalah potret batin manusia, yaitu jiwa dan kepribadiannya. ${ }^{14}$

Al-Jurjani mengatakan, al-khuluq (akhlak) adalah tabiat yang tertanam dalam jiwa yang mendorong untuk melakukan perbuatan dengan mudah tanpa perlu berpikir dan mempertimbangkan terlebih dahulu. ${ }^{15}$

b. Pengertian Pendidikan Karakter

Pendidikan Karakter merupakan sebuah istilah yang semakin hari semakin mendapat perhatian dari masyarakat lndonesia saat ini. Terlebih dengan dirasakannya berbagai ketimpangan hasil pendidikan dilihat dari perilaku lulusan pendidikan formal saat ini, semisal korupsi yang sudah mengakar dan kronis, perkembangan seks bebas pada kalangan remaja dan orang tua, narkoba, tawuran pelajar mahasiswa dan antar kampung, pembunuhan, perampokan, begal, dan pengangguran lulusan sekolah menengah atas dan perguruan tinggi. Semuanya lebih terasa dan kuat ketika negeri ini dilanda multi krisis dimensional. 
Pendidikan Karakter menurut Pusat Bahasa Depdiknas adalah bawaan, hati, jiwa, kepribadian, budi pekerti, personalitas, sifat, tabiat, temperamen, watak. Adapun berkarakter adalah berkepribadian, berperilaku, bersifat, bertabiat, dan berwatak. ${ }^{16}$

Pendidikan Karakter menurut Ratna Megawati adalah sebuah usaha mendidik anak-anak agar dapat mengambil keputusan dengan bijak dan mempraktekkannya dalam kehidupan sehari-hari, sehingga mereka dapat memberikan kontribusi yang positif kepada lingkungannya. ${ }^{17}$

Pendidikan Karakter juga sering disebut dengan pendidikan nilai. Karakter adalah value in action, nilai yang diwujudkan dalam tindakan. Pendidikan Karakter menghadirkan, menyemaikan dan mengembangkan nilai-nilai kebaikan pada diri peserta didik, diharapkan dapat mewujudkan perilaku baik. ${ }^{18}$

Selanjutnya, Akhmad Sudrajat menegaskan bahwa pendidikan karakter berpijak dari karakter dasar manusia, yang bersumber dari nilai agama yang juga disebut sebagai the golden rule. ${ }^{19}$

Individu yang berkarakter baik atau unggul adalah seseorang yang berusaha melakukan hal-hal yang terbaik terhadap Tuhan, dirinya, sesama, lingkungan, bangsa dan negara serta dunia internasional pada umumnya dengan mengoptimalkan potensi (pengetahuan) dirinya dan disertai dengan kesadaran, emosi dan motivasi (perasaannya). ${ }^{20}$

Pendidikan karakter adalah upaya sistem penanaman nilai-nilai karakter kepada warga madrasah yang meliputi komponen pengetahuan, kesadaran atau kemauan, dan tindakan untuk melaksanakan nilai-nilai yang terkandung dalam ajaran agama lslam.

Pendidikan karakter merupakan upaya yang dirancang dan dilaksanakan untuk membantu peserta didik memahami nilai-nilai perilaku manusia yang berhubungan dengan Allah Subhanahu Wa Ta'ala, diri sendiri, sesama manusia, lingkungan, dan kebangsaan yang terwujud dalam pikiran, sikap, perasaan, perkataan, dan perbuatan berdasarkan norma-norma agama, hukum, tata krama, budaya, dan adat istiadat. ${ }^{21}$

3. Tujuan Pendidikan Karakter

Secara operasional Tujuan Pendidikan Karakter dalam setting sekolah/madrasah menurut Doni Koesuma ${ }^{22}$ adalah :

a. Menguatkan dan mengebangkan nilai-nilai kehidupan yang dianggap penting dan perlu sehingga menjadi kepribadian peserta didik yang khas sebagaimana nilai-nilai yang dikembangkan

b. Mengoreksi perilaku peserta didik yang tidak sesuai dengan nilai-nilai yang dikembangkan oleh madrasah

c. Membangun koneksi yang harmoni dengan keluarga dan masyarakat dalam memerankan tanggung jawab karakter bersama. 
Tujuan pertama Pendidikan karakter adalah memfasilitasi penguatan dan pengembangan nilai-nilai tertentu sehingga terwujud dalam perilaku anak didik, baik pada saat proses pembelajaran di madrasah maupun setelah lulus. Penguatan dan pengembangan memiliki makna bahwa pendidikan dalam setting madrasah bukan merupakan dogmatis nilai, tetapi sebuah proses yang membawa peserta didik agar memahami dan merefleksi pentingnya mewujudkan nilai-nilai dalam perilaku keseharian. Pengutan juga mengarahkan proses pembiasaan yang dilakukan, baik dalam setting kelas maupun madrasah. Penguatan memiliki makna adanya hubungan antara penguatan perilaku melalui pembiasaan di madrasah.

Tujuan kedua Pendidikan karakter di madrasah mengoreksi perilaku peserta didik yang tidak sesuai dengan nilai-nilai yang dikembangkan madrasah. Tujuan ini memiliki arti bahwa Tujuan Pendidikan Karakter memiliki sarana untuk meluruskan berbagai perilaku negatif diubah menjadi perilaku positif. Proses penelusuran yang dimaknai sebagai koreksi perilaku, dipahami sebagai proses pedagogik bukan untuk untuk paksaan, atau pengkondisian yang tidak mendidik. Proses pedagogik dalam koreksi perilaku negatif diarahkan pada pola pikir anak. Lalu diiringi dengan keteladanan di lingkungan madrasah dan rumah, selanjutnya proses pembiasaan berdasarkan tingkat jenjang madrasah.

Tujuan ketiga Pendidikan karakter adalah setting madrasah membangun koneksi yang harmonis dengan keluarga dan masyarakat dengan memerankan tanggung jawab pendidikan karakter secara bersama. Tujuan ini berarti bahwa karakter di madrasah harus dihubungankan dengan proses pendidikan di keluarga. Jika pendidikan di madrasah hanya bertumpu pada interaksi peserta didik dengan guru di kelas, maka pencapaian berbagai karakter yang diharapkan akan sulit tercapai. Disebabkan penguatan perilaku merupakan suatu hal yang holistik (menyeluruh), bukan satu rentang tertentu pada masa usia anak. Dalam setiap menit dan detik, interaksi anak dengan lingkungannya dapat dipastikan akan terjadi proses mempengaruhi perilaku anak. $^{23}$

\section{Sejarah Singkat Nabi Muhammad Sallahu 'Alaihi Wa Sallam}

Beliau adalah Muhammad bin Abdullah bin Abdul Mutholib bin Hasyim dari suku Quraisy. suku Quraisy itu berasal dari bangsa Arab dari keturunan Nabi lsmail putra Nabi lbrahim.

Nabi Muhammad Sallahu 'Alaihi Wa Sallam dilahirkan di Makkah alMukarromah, pada hari Senin tanggal 12 Rabi'ul Awal tahun gajah, bertepatan dengan 21 Agustus 571 Masehi, dan wafat di Madinah 12 Rabi'ul Awal 11 Hijriyah (615). Beliau diangkat menjadi nabi pada usia 40 tahun. kemudian Beliau berda'wah dalam waktu sekitar 23 tahun, 13 tahun di Makkah dan 10 tahun di Madinah. 
Ayahnya Abdullah putra Abdul Muthalib dari kabilah Bani Hasyim. Ibunya bernama Aminah, putri Wahab dari Bani Zuhrah.

Nabi dilahirkan dalam keadaan yati, karena ayahnya sudah meninggal dunia ketika Beliau berusia 6 bulan dalam kandungan ibunya. Kemudian Beliau diserahkan kepada ibu pengasuh bernama Halimah Sa'diyah sampai berusia 6 tahun. Setelah itu, sekitar 2 tahun berada dalam asuhan ibu kandungnya. Aminah meninggal dunia pada saat Beliau berusia 6 tahun. $^{24}$

Selanjutnya Nabi diasuh oleh kakeknya Abdul Muthalib selama dua tahun. Kemudian dia juga meninggal dunia. Selanjutnya Nabi diasuh oleh pamannya Abu Thalib yang juga sangat disegani dan dihormati oleh kaum Quraisy dan semua penduduk Makkah. Abu Thalib memelihara Beliau dengan sebaik-baiknya, bahkan membela dengan segala kemampuannya ketika beliau diangkat menjadi rasul. ${ }^{25}$

Pada usianya yang semakin matang dengan berbagai pengalaman hidup telah dijalaninya dengan sukses pada usia sekitar 40 tahun. Nabi Muhammad Sallahu 'Alaihi Wa Sallam telah diberi ilham oleh Allah untuk fokus pada hal-hal yang bersifat spiritual. Kegalauan Beliau terhadap kondisi kaumnya semakin nampak. Akhirnya Beliau berkhalwat (menyendiri/kontemplasi) di Gua Hira, beberapa kilometer di utara Makkah. Di sana beliau bertafakkur berbulan-bulan. Pada tanggal 17 Ramadhan Beliau menerima wahyu pertama yang disampaikan oleh Malaikat Jibril dalam Surat Al-'Alaq ayat $1-5$ :

"Bacalah dengan menyebut nama Tuhanmu yang Menciptakan. Dia telah menciptakan manusia dari segumpal darah. Bacalah, dan Tuhanmulah Yang Maha Pemurah, yang mengajarkan manusia dengan perantaraan qalam, Dia mengajar kepada manusia apa yang tidak diketahui"26

Pada tahun ke 12 masa kerasulan Nabi Muhammad Sallahu 'Alaihi Wa Sallam Beliau di lsro' wal Mi'roj oleh Allah Subhanahu Wa Ta'ala pada malam 27 Rajab. Setelah terjadinya peristiwa yang sangat luar yang belum pernah dialami oleh Rasul sebelum Beliau dan akan pernah terjadi setelah kenabian Beliau, kepercayaan penduduk Yatsrib tentang kerasulan Beliau semakin meningkat. Sebagian orang Yatsrib dari kaum Aus dan Khazraj yang datang ke Makkah menyatakan masuk lslam dan berjanji setia, serta merindukan perdamaian. Pada musim haji, jamaah yang datang dari Yatsrib berjumlah 73 orang secara terang-terangan meminta kepada Nabi Muhammad Sallahu 'Alaihi Wa Sallam agar berkenan pindah ke Yatsrib. Permohonan tersebut direspon oleh Nabi Muhammad Sallahu 'Alaihi Wa Sallam.

Setelah adanya permohonan tersebut maka orang kafir Quraisy semakin meningkatkan teror, intimidasi dan penindasan terhadap kaum muslimin para pengikut Nabi. Dalam waktu dua bulan, hampir semua kaum muslimin yang berjumlah 150 orang, telah meninggalkan kota Mekkah menyusul Nabi Muhammad nama Yatsrib diubah menjadi Madinatur Rasul, atau juga disebut dengan Madinatul Munawwaroh, karena dari sanlah lslam tersebar ke berbagai pelosok penjuru bumi. 
Selama berada di Madinah Nabi Muhammad Sallahu 'Alaihi Wa Sallam tidak hanya tampil sebagai kepala agama, tetapi juga sebagai kepala negara dan pemerintahan yang mengatur, menertibkan, menata, membina, dan menyembangkan kehidupan masyarakat dalam berbagai aspek bidang politik, ekonomi, sosial, budaya, hukum, pendidikan dan da'wah.

Dalam melaksanakan tugas tersebut, khususnya dalam menjalankan da'wah lslam menegakkan kalimat tauhid ke berbagai daerah wilayah Arab, dalam rangka mewujudkan perdamaian mendapat tantangan hambatan dan penolakan bahkan perlawanan dari berbagai suku, kelompok masyarakat, dan raja-raja di sekitar Jazirah Arabia. Penolakan dan perlawanan tersebut terkadang diselesaikan melaui jalan peperangan. Untuk itu Nabi Muhammad Sallahu 'Alaihi Wa Sallam secara terpaksa terlibat dalam perang tersebut setelah mendapatkan ijin dari Allah untuk berperang melawan kelompok orang yang zhalim. ${ }^{27}$

\section{Akhlak Nabi Muhammad Sallahu 'Alaihi Wa Sallam}

Nabi Muhammad Sallahu 'Alaihi Wa Sallam adalah contoh dan teladan yang baik dalam berbagai aspek kehidupan, mulai kehidupan berkeluarga, bermasyarakat sampai kehidupan berbangsa dan bernegara, sebagai bukti kuat atas kenabian beliau. Keagungan akhlaknya diakui sendiri oleh Allah Subhanahu Wa Ta'ala, dalam firmanNya :

"Dan sungguh kamu benar-benar berbudi pekerti yang agung"28

Diriwayatkan dari Aisyah, ketika ditanya oleh para sahabat tentang akhlak Rasulullah Sallahu 'Alaihi Wa Sallam, dia menjawab :

"Akhlak beliau adalah Al-Qur'an"29

Nabi Muhammad Sallahu 'Alaihi Wa Sallam selalu berperilaku sesuai atas kandungan ayat Al-Qur'an. Kepatuhan beliau terhadap perntah Rabbnya, itulah yang menjadi akhlak dan karakter beliau. ${ }^{30}$

Sebagai guru yang mulia, pendidik yang agung, dan sebagai uswah hasanah bagi manusia Nabi Muhammad Sallahu 'Alaihi Wa Sallam benar-benar memiliki akhlak yang agung sebagaimana diakui dan dipuji langsung oleh Allah Subhanahu Wa Ta'ala.

Berikut ini beberapa contoh akhlak dan karakter Nabi Muhammad Sallahu 'Alaihi Wa Sallam yang berkaitan dengan posisi beliau sebagai seorang guru dan pendidik, terutama yang berkaitan dengan pendidikan karakter.

a. Amanah 
Amanah adalah akhlak mulia yang dimiliki beliau sebelum dan sesudah diangkat menjadi Nabi. Masyarakat Quraisy Makkah ketika itu menjulukinya sebagai "al-amin", artinya yang dapat dipercaya, karena kejujuran dan amanah beliau.

Amnah secara bahasa artinya dapat dipercaya. Secara istilah, amanah memiliki arti khusus dan umum. Arti khusus adalah sikap bertanggung jawab orang yang dititipi barang atau benda lainnya dengan mengembalikannya kepada orang yang memilikinya. Adapun arti secara umum misalnya menyimpan rahasia, tulus dalam memberikan masukan kepada orang yang meminta pendapat, dan menyampaikan pesan kepada pihak yang benar. ${ }^{31}$

Sifat amanah berhubungan erat dengan berbagai sifat mulia lainnya, seperti jujur, sabar, berani, menjaga kemuliaan diri, memenuhi janji dan adil. Adapun lawan sifat amanah adalah khianah. Nabi Muhammad Sallahu 'Alaihi Wa Sallam memasukkan sifat khianah ini ke dalam sifat orang munafik. Beliau bersabda :

"Tanda-tanda orang munafik ada tiga, kalau bicara dusta, kalau berjanji mengingkari, kalau dipercaya khianat" ${ }^{32}$

b. Jujur (ash-Shidq)

Jujur (ash-Shidq) adalah akhlak yang mulia. Beliau selalu menganjurkan umatnya selalu menghiasi diri dengan akhlak yang agung ini. Hadits Nabi yang menerangkan kebaikan sifat jujur dan keburukan kebiasaan berbohong. Diriwayatkan dari lbnu Mas'ud, bahwa Nabi Muhammad Sallahu 'Alaihi Wa Sallam bersabda :

"Berlaku jujurlah kalian, karena kejujuran akan mengantarkan kepada kebaikan, dan kebaikan akan mengantarkan ke sorga. Ketika seseorang selal jujur dan menjaga kejujurannya, Allah Subhanahu Wa Ta'ala akan menetapkannya sebagai orang yang jujur. Janganlah kalian berbohong karena kebohongan akan mengantarkan kepada perbuatan dosa, dan perbuatan dosa akan mengantarkan masuk neraka. Jika seseorang selalu berbohong dan membiasakan diri berbohong, maka Allah akan menetapkannya sebagai pembohong" "33

Jujur mempunyai banyak definisi, namun ada satu makna yang sering digunakan dan mdah dipahami, yaitu perkataan yang benar sesuai dengan realita yang dilihat oleh orang yang mengatakanya meskipun orang lain tidak mengetahuinya. ${ }^{34}$

Nabi Muhammad Sallahu 'Alaihi Wa Sallam adalah contoh dan teladan yang paling baik. Sebelum diutus menjadi nabi, masyarakat Qraisy sudah memanggilnya dengan julukan ash-shadiq al-amin (orang yang jujur dan dapat dipercaya) ${ }^{35}$

Raghib as-Sirjani mengatakan : Yang datang membawa kebenaran/kejujran adalah Nabi Muhammad Sallahu 'Alaihi Wa Sallam. Sedangkan yang bersaksi terhadap apa yang dibawa oleh beliau adalah Allah di dalam Al-Qur'an. ${ }^{36}$

c. Lemah Lembut (al-Hilm) 
Islam menganjurkan umatnya bersikap lemah lembut, karena sifat ini adalah kebalikan dari sifat pemarahakibat dorongan nafsu ammaroh.

Kelemah lembutan menurut lmam Ghazali dengan kalah dan tunduknya potensi kemarahan terhadap bimbingan akal. Tumbuhnya sifat lemah lembut dalam diri manusia dapat dimulai dengan melatih diri menahan amarah. Allah Subhanahu Wa Ta'ala, berfirman : orang",37

"Dan orang-orang yang menahan amarahnya dan memaafkan kesalahan

Dalam sejarah kehidupan Nabi Muhammad Sallahu 'Alaihi Wa Sallam banyak sekali catatan tentang kejadian yang menggambarkan sikap kelemah lembutan beliau. Di antaranya sewaktu perang Uhud para sahabat meminta Nabi melaknat orang-orang kafir yang melukai wajah beliau dan giginya patah, namun ditolaknya permintaan sahabat tersebut, bahkan beliau berkata, "Sungguh saya diutus bukan sebagai tukang laknat. Saya diutus sebagai da'i dan penyebar kasih sayang. Ya Allah ampunilah kaumku, sesungguhnya mereka tidak mengetahui (akibat dari apa yang mereka lakukan)" "38

\section{d. Kasih Sayang (Rahmah)}

Kasih Sayang (Rahmah) adalah salah satu sifat Allah. Di antara bentuk keagungan kasih sayang Allah adalah dengan mengutus Nabi Muhammad Sallahu 'Alaihi Wa Sallam sebagai kasih sayang (rahmah) untuk seluruh umat manusia dan untuk mengeluarkan mereka dari gelap menuju cahaya. Allah Subhanahu Wa Ta'ala, berfirman :

"Tidaklah Kami mengutus kamu, melainkan untuk menjadi rahmat bagi semesta alam"39

Nabi Muhammad Sallahu 'Alaihi Wa Sallam bersabda :

"Wahai manusia sungguh aku adalah rahmat yang dihadiahkan kepada alam semesta" 40

e. Tawadhu' (Rendah Hati)

Secara sederhana Tawadhu' artinya Rendah Hati, tidak sombong. Adapun arti yang mendalam Tawadhu' artinya sikap Rendah Hati, namun tidak sampai merendahkan kehormatan diri dan tidak pula memberi peluang orang lain merendahkan kemuliaan diri.

Lawan tawadhu' adalah sombong. Tawadhu' merupakan bagian akhlak mulia, sedangkan kesombongan termasuk akhlak yang tercela. 
Nabi Muhammad Sallahu 'Alaihi Wa Sallam adalah teladan utama dalam masalah tawadhu', meskipun beliau adalah manusia yang paling sempurna dan paling mulia di sisi Allah, tetapi beliau tidak pernah sombong, bahkan beliau merendahkan diri dengan mencintai para sahabat, kerabat, dan anak-anaknya, hingga merekapun mencintai dan memuliakan Nabi, bahkan lebih mementingkan kebutuhan Rasulullah dari pada kebutuhan mereka sendiri. ${ }^{41}$

Nabi Muhammad Sallahu 'Alaihi Wa Sallam dengan seluruh akhlaknya yang sempurna merupakan sosok pribadi yang rendah hati. Keadaan ini tidak berganti dan tidak berubah. Jiwanya selalu berhubungan dengan langit, tetapi beliau selalu menjadi pijakan norma-norma sosial lslam yang menjadikan semua manusia berkedudukan setara dalam bingkai ukhuwah lslamiyah. Tidak seorangpun terangkat derajatnya karena kaya atau berpangkat, karena jabatan atau turunan (nasab).

Tawadhu' merupakan sifat terpuji yang dicintai Allah dan Rasul. Siapa yang tawadhu' niscaya Allah akan mengangkat derajatnya di dunia dan di akhirat.

\section{Metode Pendidikan Karakter Nabi Muhammad Sallahu 'Alaihi Wa Sallam}

Pengertian metode tidak sekedar diartikan sebagai cara mengajarkan sesuatu, tetapi lebih dari itu metode dipandang sebagai upaya perbaikan komprehensif dari semua elemen pendidikan, sehingga menjadi sebuah iklim yang mendukung tercapainya tujuan pendidikan. Oleh karena itu seluruh aktivitas pendidikan Nabi dapat dikategorikan sebagai metode pendidikannya. ${ }^{42}$

Dalam mengajar dan mendidik, Nabi Muhammad Sallahu 'Alaihi Wa Sallam selalu memilih dan menggunakan metode terbaik. Beliau telah memformulasikan sistem dan metode pendidikan yang memiliki kekhasan tersendiri. Metode yang disampaikan beliau sangat mengesankan, sehingga memudahkan dan sangat membantu dalam memahami suatu ajaran atau permasalahan.

Rasulullah memilih metode yang mudah diingat dan tertanam kuat dalam memori para sahabat. Ketika itu para sahabat mencurahkan daya ingatnya yang luar biasa untuk menerima dan menyimpan ilmu yang diajarkan nabinya. ${ }^{43}$

Berikut ini beberapa metode Nabi Muhammad Sallahu 'Alaihi Wa Sallam yang berkaitan laingsung dengan pendidikan karakter dalam mendidik dan mengajar para sahabat, yang menghasilkan manusia-manusia hebat sepanjang sejarah lslam.

\section{a. Keteladanan (uswah Hasanah)}

Dalam proses pembelajaran yang membutuhkan praktek langsung. Nabi selau melakukannya dengan memberikan contoh langsung, tidak hanya teori, bahkan beliau melakukannya terlebih dahulu sebelum disampaikan kepada para sahabat. 
Pada dasarnya ilmu yang disampaikan dengan praktek langsung memiliki pengaruh lebih besar dan ilustrasinya akan menancap lebih kuat di hati dan memori anak didik. $^{44}$

Pengajaran melalui contoh nyata memiliki dua bentuk Pertama, guru melakukan sesuatu yang dia perintahkan kepada anak didik, atau menjauhi sesuatu yang dilarang. Guru menjadikan sikap dan perilakunya sebagai teladan bagi anak didiknya. Kedua, guru menjelaskan apa yang diucapkan lalu mengiringinya dengan praktek. Ada peribahasa yang mengatakan," perkataan yang disertai dengan perbuatan lebih dapat menjelaskan dan lebih meresap ke dalam jiwa pendengar dari pada ucapan semata".

Imam lbnu Abi Jamroh berkata, "Mengajari dengan perbuatan dan contoh lebih mengena dari pada ucapan semata". Nabi kita yang mulia menggunakan kedua pola pengajaran tersebut sekaligus. ${ }^{45}$

\section{b. Melatih dan Membiasakan}

Menurut lmam Ghazali metode melaih anak merupakan perkara yang terpenting dan paling utama. Anak adalah amanah bagi kedua orang tuanya. Hatinya yang suci merupakan perhiasan yang sangat berharga. Bila anak dilatih untuk mengerjakan kebaikan, maka akan tumbuh menjadi anak yang baik dan bahagia dunia akhirat. Sebaliknya bila anak dibiarkan mengerjakan keburukan dan dibiarkan begitu saja bagaikan hewan, anak akan hidup sengsara dan binasa. ${ }^{46}$

Bila anak terbiasa dengan etika, akhlak, dan nilai-nilai yang baik sejak masa kecil, maka akan tumbuh besar dan akrab dengan nilai dan kebiasaan mulia, sehingga anak dengan mudah diarahkan dan dididik kepada kebaikan dan kemuliaan, serta d masa tuanya tinggal menikmati hasilnya karena masa tua terbiasa dengan kondisi di masa kecil dan muda. ${ }^{47}$

Nabi Muhammad Sallahu 'Alaihi Wa Sallam adalah guru agung dan mulia telah mencanangkan pendidikan sejak usia dini, meminta para orang tua dan guru menjadi teladan bagi anak didiknya. Nabi memerintahkan kepada orang tua untuk menanamkan iman sejak anak di masa kecil, melatih dan membiasakan akhlak dan karakter yang baik. Beliau mencontohkan dengan menggendong cucunya Hasan dan Husin ke masjid untuk shalat berjamaah.

\section{c. Membimbing Mengarahkan dan Nasehat}

Pada anak usia dini, orang tua harus banyak memberikan pengarahan, bimbingan dan pendidikan kepada anak secara maksimal, baik dalam bentuk perintah maupun larangan, ataupun dalam bentuk motivasi dalam ajak kepada perbuatan baik maupun peringatan pada perbuatan tercela. ${ }^{48}$

Berdasarkan Hadits Nabi Muhammad Sallahu 'Alaihi Wa Sallam, bahwa setiap anak dilahirkan dalam keadaan fitrah, yaitu cenderung pada kebaikan, maka selanjutnya kondisi anak sangat tergantung, kepada pendidikan, arahan, dan bimbingan orang tua. 
Usia dini merupakan masa bagi anak memiliki kemampuan yang sangat besar dalam menghafal dan meniru.

Para pendidik hendaknya memanfaatkan peluang yang sangat besar dalam mendidik anak usia dini sebaik mungkin. Umar Bin Khothob berkata, "Ajarilah anakanakmu beberapa nilai kebaikan, dan di antara kebaikan adalah mengarahkan anak agar menghafal Al-Qur'an,as-Sunnah, dan masalah fiqih". Orang tua harus membuat atau menyiapkan permainan anak yang bagus dan mendidik, serta mengembangkan daya nalar dan kreatifitas anak terutama kemampuan untuk meniru dan menghafal harus diberdayakan semaksimal mungkin. ${ }^{49}$

Anak dan peserta didik juga perlu diberikan nasehat (mau'izhoh) dan peringatan (tadzkiroh). Metode nasehat dan peringatan merupakan metode yang sangat penting dan dominan yang sering digunakan oleh Nabi Muhammad Sallahu 'Alaihi Wa Sallam dalam mengajar dan mengarahkan umat lslam ke jalan yang baik. ${ }^{50}$ Metode ini sering diaplikasikan beliau, sebagaima firman Allah :

"Dan tetaplah memberi peringatan, karena sungguh peringatan itu bermanfaat bagi orang yang beriman" 51

Nasehat yang baik termasuk sarana yang dapat menghubungkan jiwa anak didik dengan cepat, karena jiwa manusia dapat terpengaruh yang disampaikan berupa katakata. Apa lagi kalau kata-kata itu dihiasi dengan keindahan, lunak, santun, dan mudah dipahami, tentu saja dapat menggetarkan hatinya. ${ }^{52}$

\section{d. Metode Kisah}

Mendidik melalui cerita yang mengandung pelajaran dan peringatan merupakan salah satu bentuk nasehat yang paling efektif. Karena secara naluri jiwa manusia tertarik pada cerita dan menerimanya dengan sepenuh hati. Apabila cerita itu mengandung hikmah dan pelajaran ada tujuan yang hendak dicapai. Ketika Al-Qur'an menceritakan kisah-kisah bukan semata untuk hiburan dan mengisi waktu luang, tetapi untuk tujuan pendidikan dan menanamkan nilai-nilai iman dan akhlak yang terpuji. ${ }^{53}$

Metode kisah telah lama digunakan dalam dunia pendidikan untuk menanamkan pelajaran dan nilai-nilai moral melalui media cerita dan kisah. Metode tersebut sangat efektif untuk menyampaikan pesan, karena anak didik bisa dengan mudah mengambil pelajaran dan ibroh dari kisah yang terjadi. Metode ini juga sangat baik jika diterapkan di kalangan remaja kelompok usia yang cenderung dipaksa belajar, dan cenderung tidak mau digurui dengan alasan sedang mencari identitas dan jati diri. ${ }^{54}$

Dengan metode kisah, anak didik sebagai pendengar secara alamiah dibiarkan mengambil dan memetik sendiri hikmah yang terkandung dalam cerita tersebut yang disampaikannya. Cerita bisa menarik pendengarnya untuk berinteraksi dan mengikuti dengan segenap perasaan, pikiran, emosi, dan menyatu ke dalam apa yang didengarnya, ${ }^{55}$ 
Tujuan dari cerita atau kisah adalah untuk mengambil manfaat dan ibroh dari kisah tersebut. Sebagaimana disebutkan dalam firman Allah :

"Sungguh pada kisah-kisah mereka terdapat pelajaran bagi orang-orang yang mempunyai akal. Al-Qur'an itu bukanlah cerita yang dibuat-buat, tetapi membenarkan kitab-kitab sebelumnya yang menjelaskan segala sesuatu, sebagai petunjuk dan rahmat bagi kaum yang beriman" 56

Al-Qur'an banyak memuat kisah-kisah, baik kisah pata nabi maupun kisah para umat terdahulu. Bahkan seperempat sampai sepertiga bagian dari Al-Qur'an berisi cerita. Teknik penyampaiannya dinilai para ulama memiliki keistimewaan yang paling unggul. Syaikh Manna al-Qaththan menyebutkan, "Kisah-kisah nyata dalam AlQur'an telah membuktikan bahwa redaksi kearaban yang dimuatnya secara jelas menggambarkan kisah-kisah yang lebih tinggi nilainya". ${ }^{57}$

Nabi Muhammad Sallahu 'Alaihi Wa Sallam menggunakan metode cerita karena beliau memandang bahwa metode ini yang paling kuat untuk memperkuat gagasan dalam mencapai sasaran. Rasulullah telah menggunakan metode tersebut dengan menceritakan kisah bangsa-bangsa terdahulu yang telah punah, atau kisah orang-orang pada masa nabi sebelumnya agar para sahabat dapat mengambil sendiri pelajaran dan hikmah dari kisah yang nabi ceritakan. ${ }^{58}$

Metode kisah memiliki pengaruh yang sangat besar bagi jiwa anak didik yang mendengar atau melihatnya. Karena itu Nabi Muhammad Sallahu 'Alaihi Wa Sallam menjadikan metode kisah ini sebagai salah satu metode pendidikan beliau. Demikian pula para pendidik dan para orang tua diharapkan menggunakan metode ini sebagai metode dalam mendidik anak didik.

e. Menjelaskan dengan perumpamaan

Adakalanya Nabi Muhammad Sallahu 'Alaihi Wa Sallam menyampaikan pelajaran kepada para sahabat melalui perumpamaan atau tamsil. Menurut lbnul Qayyim yang dimaksud dengan perumpamaan/tamsil adalah menyerupakan status hukum dari dua hal yang berbeda, atau memahamkan sesuatu yang abstrak kepada sesuatu yang kongkret (dapat diraba), atau memahamkan suatu yang konkret melalui hal yang kongkret lainnya, yaitu dengan mengacu pada salah satu dari keduanya. ${ }^{59}$

Tujuan metode permpamaan untuk memahamkan sesuatu yang bersifat abstrak kepada orang diajak bicara dengan cara menyampaikannya kepada sesuatu yang bersifat kongkret. Atau menyerupakan sesuatu yang bersifat kongkrit lain yang lebih jelas. $^{60}$

Kiasan-kiasan (perumpamaan) yang ada dalam Al-Qur'an dan Hadits memiliki tujuan dalam kontek kejiwaan dan pendidikan yang bisa direalisasikan mengingat tingginya nilai dan tujuan yang terkandung di dalamnya, di samping keindahan bahasa dan pengarus penyampainnya. ${ }^{61}$ 
Tujuan metode Kiasan-kiasan (perumpamaan) dalam konteks pendidikan antara lain:

1) Mendekatkan makna kepada pemahaman, karena manusia sedah akrab dengan perumpamaan hal yang abstrak dengan hal yang kongkret, agar bisa memahami agar bisa memahami hal-hal yang konsepsional atau hal-hal yang tidak kasat mata.

2) Membangkitkan emosi yang sesuai dengan makna dan melatih perasaanperasaan yang rabbani, seperti merasakan kehinaan dan kebodohan mereka.

3) Melatih akal untuk berfikir secara benar, dan menggunakan analogi yang logis dan benar. Sebagian kiasan menyimpan analogi yang disebutkan mukaddimahnya saja, kemudian akal ditunut untuk mencari kesimpulan yang sering kali tidak dinyatakan secara tegas dalam Al-Qur'an

4) Membangkitkan emosi, perasaan dan keinginan untuk berbuat baik dan menghindari kemunkaran.

f. Lemah Lembut

Allah telah menanamkan pada diri Nabi Muhammad Sallahu 'Alaihi Wa Sallam sikap lembut, ramah,dan sayang terhadap para sahanat dan umat lslam sebagaima firman Allah :

"Maka disebabkan rahmat dari Allah lah kamu berlaku lemah lembut terhadap mereka. Sekiranya kamu bersikap keras lagi berhati kasar, tentulah mereka menjauhkan diri dari sekelilingmu" 62

Nabi Muhammad Sallahu 'Alaihi Wa Sallam selalu berinteraksi dengan para sahabat selaku muridnya dengan penuh kasih sayang dan kelembutan. Kelembutan sikap nabi ketika mengajar terekam jelas dalam sejarah beliau yang suci.

Dalam suatu riwayat lmam Bukhari, dari Abi Hurairah berkata, "Seorang Badui telah kencing di masjid, maka orang-orang mendatangi untuk memukulnya, lalu Nabi Muhammad Sallahu 'Alaihi Wa Sallam bersabda: Biarkanlah dia, dan tuangkanlah pada kencingnya itu satu ember air atau satu timba air. Sesungguhnya kalian ditugaskan untuk berbuat mempermudah dan tidak ditugaskan untuk mempersulit"63

g. Memberi Pujian dan Memuliakan

Dalam pendidikan moderen, pemberian pujian (reward), baik berupa pujian, penghargaan maupun hadiah bagi yang berprestasi sangat dianjurkan, untuk memotivasi anak didik agar semakin giat untuk berlomba dan berprestasi. Metode ini sudah digunakan Nabi Muhammad Sallahu 'Alaihi Wa Sallam lima belas abad yang lalu. Nabi suka menyukai pertanyaan yang bagus, beliau memuji pertanyaan itu yang membuat penanya merasa senang. 
Nabi Muhammad Sallahu 'Alaihi Wa Sallam memuji bagusnya pertanyaan Mu'adz bin Jabal, dengan sabda beliau, :Bagus, sungguh engkau telah menanyakan sesuatu yang sangat berbobot". ${ }^{64}$

Pujian dan sanjungan membawa dampak besar dalam jiwa anak didik. Pujian dapat menggerakkan perasaannya, sehingga anak dapat segera memperbaiki peilaku dan perbuatannya. Hatinya akan merasa senang mendengar pujian, dan akan terus melakukan perbuatan yang terpuji.

Dalam siroh nabi yang mulia disebutkan bahwa adakalanya beliau memuliakan dan memuji para sahabat yang memiliki keutamaan khusus. Metode ini sangat memotivasi anak didik didik konsisten dalam menuntut ilmu, mengerjakan amal kebaikan, dan melakukan perbaikan. ${ }^{65}$

h. Meluruskan Kesalahan

Dalam masa pembinaan para sahabat sebagai kader utama, tentunya tidak luput dari pantauan Nabi Muhammad Sallahu 'Alaihi Wa Sallam. Para sahabat sebagai manusia biasa tidak luput dari kesalahan. Jika itu terjadi maka Rasulullah segera Meluruskan Kesalahan tersebut dengan berbagai metode pendidikan. Adakalanya dengan teguran langsung, sindiran, atau mungkin pemutusan hubungan dari jamaah, atau isolasi sebentar. ${ }^{66}$

Dengan metode teguran langsung seperti ini, hasilnya lebih efektif bisa dirasakan. Yang melakukan kesalahan segera diluruskan, akan menyadari keslahan dan tidak mengulangi lagi keslahan tersebut. Teguran langsung yang bijak dan santun akan membuat pembelajaran lebih meresap dan membekas pada anak didik.

\section{i. Metode Ganjaran}

Metode Ganjaran ini erat kaitannya dengan metode meluruskan apabila anak didik melakukan kesalahan. Jika segala metode sudah dilakukan dan belum berhasil, anak didik masih melakukan kesalahan, dan cenderung melanggar aturan madrasah, maka anak didik memerlukan pengobatan berupa sanksi atau hukuman. Ini dilakukan agar dia sadar tentang kesalahan yang dilakukannya menjadi masalah serius dan tidak main-main. Dengan merasakan ganjaran dengan hukuman, anak didik dapat menyadari nilainya kasih sayang dan kelembutan dari pendidik selaku orang tua pengganti di madrasah. Dia juga dapat meresakan pentingnya disiplin dan taat aturan yang berlaku di madrasah, sehingga diharapkan tidak mengulangi lagi kesalahannya, dan berperilaku yang baik.

Tujuan menjatuhkan hukuman dalam pendidikan lslam untuk memberikan bimbingan dan perbaikan, bukan untuk pembalasan atau kepuasan hati. Karena itu 
watak dan kondisi anak didik harus diperhatikan terlebih dahulu sebelum menjatuhkan sanksi berupa hukuman. Seorang prndidik harus menerangkan kekeliruan yang dilakukan anak didik dan memberi dorongan uuntuk memperbaiki diri. Kesalahan dan kekhilafannya harus dimaafkan, jika anak didik tersebut telah memperbaiki diri. ${ }^{67}$

\section{Metode Pembelajaran Nabi Muhammad Sallahu 'Alaihi Wa Sallam}

Metode sangat ampuh dan jitu dalam memdidik peserta didik. Metode keteladanan (uswah) menempati posisi utama, karena demikianlah kesuksesan Nabi Muhammad Sallahu 'Alaihi Wa Sallam dalam mendidik umatnya. Kemudian dilanjutkan dengan metode melatih dan pembiasaan, kemudian dilanjutkan kepada metode ganjaran (hukuman) jika ada yang perlu dihukum. Dr. Saad Riyadh ketika membahas metode pendidikan Nabi, para murid di madrasah ini mempelari melaui keteladanan beliau, kemudian mereka mendalaminya dengan latihan, dan mewujudkan dalam praktek langsung pada kehidupan sehari-hari. Jelas, bahwa madrasah pada zaman sekarang membutuhkan nilai-nilai luhur seperti ini. ${ }^{68}$

Di lingkungan madrasah, keteladanan guru menjadi tokoh sentral dalam memdidik peserta didik. Di masyarakat Jawa dikenal istilah, guru itu digugu dan ditiru, artinya seorang guru dipercaya dan menjadi teladan bagi anak didiknya. Apa pun yang diucapkan, dilakukan, dan diperintahkan guru akan diikuti oleh anak didiknya. Bahkan dapat mengembangkannya lebih jauh dibandingkan gurunya. ${ }^{69}$

Sepatutnya seorang guru memperhatikan penampilan, sikap, dan peri lakunya. Masykur Arif Rahman mengumpulkan ada sekitar 25 ragam kesalahan guru dalam kegiatan proses pembelajaran di madrasah, di antaranya :

1) Duduk di atas meja ketika mengajar

2) Mengajar sambil merokok

3) Mengajar sambil makan

4) Mengajar seraya bermain handphone

5) Tidur saat mengajar

6) Tidak disiplin

7) Mengajar secara monoton

8) Tidak mengoperasikan media pempelajaran

9) Sering bolos, dan lain-lain. ${ }^{70}$

Ada tiga macam Metode Pembelajaran Nabi Muhammad Sallahu 'Alaihi Wa Sallam di madrasah, yaitu :

a. Melatih dan Membiasakan

Melatih dan Membiasakan adalah hal yang penting dilaksanakan di madrasah untuk membangun karakter anak didik, terutama pada tingkat dasar. Mulai dari masalah ibadah, akhlak, kebersihan, kerapihan, sampai masalah disiplin. Misalnya membiasakan salam setiap masuk kelas, atau ketika bertemu 
guru atau sesama teman, berpakaian rapi, berdoa sebelum pelajaran dimulai, shalat dhuha, shalat berjamaah, membaca Al-Qur'an, infaq, sedekah, membuang sampah pada tempatnya, jujur dalam mengerjakan ujian, dan lain sebagainya. Bahkan sekarang di madrasah sudah ada program pengembangan diri dan pembiasaan. Masing-masing lembaga tinggal mengoptimalkan program pembiasaan tersebut ke dalam sebuah program yang tersusun dengan baik dan teratur.

\section{b. Bimbingan dan Konseling}

Metode bimbingan, pengarahan, dan nasehat sebagaimana yang dilakukan oleh Nabi Muhammad Sallahu 'Alaihi Wa Sallam, maka ada satu peluang yang dioptimalkan di madrasah yaitu guru bimbingan dan konseling (BK), di samping itu peran guru lain secara umum. Bimbingan dan Konseling memuat program bimbingan masalah pribadi, sosial,, dan karier anak didik. Jika program ini dilaksanakan dengan baik dan benar, maka hasilnya tentu akan dapat dinikmati dan dirasakan oleh semua pihak

Al-Maghribi memberikan catatan agar bimbingan dan nasehat dapat mencapai hasil yang maksimal, berupa :

1) Nasehat dan bimbingan itu hendaknya dilakukan secara terus menerus, rutinitas, dan diulang-ulang serta diperbarui, karena karakter manusia itu labil dan lupa.

2) Nasehat dan bimbingan itu hendaknya menggunalan cara yang mudah, sesuai usia, daya tangkap, dan akal anak didik.

3) Hendaknya orang yang memberikan nasehat seorang yang bijak,memiliki keilmuan tentang perkembangan anak didik yang cukup dalam mendidik.

4) Hendaknya orang yang memberikan nasehat seorang yang dapat menyesuaikan antara perbuatan dan perkataan.

5) Hendaknya orang yang memberikan nasehat seorang yang berperi laku benar, mampu memotivasi anak didik untuk dapat melakukan saran dan arahannya. ${ }^{71}$

\section{c. Evaluasi}

Sistem evaluasi yang hanya menekankan pada aspek kognitif semata, seperti pelaksanaan ujian nasional dengan beberapa mata pelajaran tertentu, tidak sesuai jika dikaitkan dengan pendidikan karakter yang diharapkan. Karena tidak memuat aspek afekti dan psikomotor, serta aspek iman dan akhlak peserta ujian nasional. Belum lagi mempermasalahkan pertimbangan antara domisili anak didik di desa dan di kota, daerah perpencil dan kota besar, antara penduduk jawa dan luar jawa, dan seterusnya. Meskipun pemerintah sudah menyatakan bahwa hasil ujian nasional bukan satu-satunya kriteria kelulusan, 
tetapi dengan sistem yang ada ini masyarakat tetap menilai bahwa kriteria kelulusan adalah hasil ujian nasional.

Sistem evaluasi pendidikan karakter Nabi Muhammad Sallahu 'Alaihi Wa Sallam, penekannya terletak pada pelaksanaan ajaran lslam. Artinya aspek afektif (sikap) dan psikomotorik (perbuatan) harus menjadi pertimbangan, dan diberi aspek yang sama dengan aspek kognitif. Ahmad Dimyati Rosyid memberi kritikan, tentang rumusan tiga ranah masih belum cukup, harus ditambah dengan konasi (akhlak) dan iman. Dilihat dari tipe hasil belajar, rumusan Bloom dkk dalam tiga domain; kognitif, afektif, dan psikomotor agaknya belum menjangkau totalitas pandangan terhadap manusia. ${ }^{72} \mathrm{Hal}$ ini karena didasarkan pada unsur manusia yang terdiri dari jasmani, ruhani, jiwa, akal, dan hati nurani. Menurut Ahmad Dimyati Rosyid, ditinjau dari hakikat manusia,, ditinjau dari hakikat manusia, maka pendidikan harus dapat mengembangkan semua aspek dan semua potensi yang ada pada diri manusia secara totalitas. Program pendidikan dikonstruksikan tidak semata-mata aspek kognitif, afektif dan psikomotor, tetapi juga menekankan konasi ${ }^{73}$ dan iman Ahmad Dimyati Rosyid sebagai bangian dari dimensi manusia. ${ }^{74}$

Tes tulis yang disebut tes formal, bukan satu-satunya alat uji kecerdasan seseorang. Tes formal saja masih belum cukup untuk dijadikan standar penilaian keberhasilan anak didik. Padahal tes formal inilah yang masih menjadi standar di negeri ini.

Kecerdasan seseorang tidak mungkin dibatasi oleh indikator yang ada dalam tes formal. Sebab setelah diteliti ternyata kecerdasan seorang itu selalu berkembang (dinamis) tidak statis. Tes yang dilakukan untuk menilai kecerdasan seseorang, praktis hanya menilai kecerdasan pada saat itu. Menurut Gardner, kecerdasan dapat dilihat dari kebiasaan seseorang. Padahal kecerdasan adalah perilaku yang diulang-ulang. ${ }^{75}$

Dengan sistem evaluasi yang imbang, maka akan berpengaruh pada pelaksanaan proses pembelajaran yang ada di dalamnya pendidikan karakter. Alasannya karena pendidikan karakter merasa mendapat tempat atau penghargaan yang sama dengan aspek kognitif.

Dimyati menulis, "Pengaruh konsep pendidikan barat dalam pendidikan nasional praktis mengesampingkan dimensi hati nurani sebagai bagian akhlak dari wujud manusia”. Pendidikan yang berdasarkan kompetensi yang sematamata menyerap sepenuhnya dari Barat melahirkan manusia intelek terampil, tetapi afektif kering. ${ }^{76}$

Pendidikan iman dan akhlak harus mendapatkan porsi yang tepat jika ingin pendidikan karakter mendapat hasil yang maksimal. Pelaksanaan ajaran agama lslam harus menjadi pertimbangan kelulusan pendidikan anak didik, 
kalau ingin pendidikan karakter berbasis lslam mencapai hasil yang maksimal. Allah telah memberikan tuntunan dalam firman-Nya :

"Katakanlah: berjalanlah kalian, maka Allah dan Rasul-Nya serta orang-orang mu akan melihat pekerjaan kalian, dan kalian akan dikembalikan kepada Allah untuk mngetahui yang mengetahui akan yang ghaib dan yang nyata, lalu diberitakan-Nya kepada kalian apa yang telah kalian kerjakan"77

Jika pendidikan karakter akan menjadi pilihan, maka pemerintah juga harus berani mengambil langkah fundamental, sebagai konsekuensinya adalah dengan meninjau ulang kurikulum saat ini yang dirasa terlalu berat. Gunanya adalah untuk memberikan ruang yang cukup bagi masuknya pendidikan karakter. Dengan padatnya beban materi dan jam pelajaran pada saat sekarang ini, akan sangat sulit pendidikan karakter dapat diberlakukan. ${ }^{78}$

\section{PENUTUP}

1. Kesimpulan

a. Konsep pendidikan karakter Nabi Muhammad Sallahu 'Alaihi Wa Sallam, adalah sebuah pendidikan yang integral, bertujuan untuk membentuk anak didik yang beriman, bertaqwa, dan berakhlak mulia.

b. Nabi Muhammad Sallahu 'Alaihi Wa Sallam, melaksanakan pendidikan karakter dengan menggunakan berbagai metode pembelajaran.

c. Aplikasi penerapan konsep dan metodologi Nabi Muhammad Sallahu 'Alaihi Wa Sallam, dalam pendidikan karakter di madrasah, antara lain : 1) penguatan kurikulum, terutama mata pelajaran agama lslam (aqidah, akhlak, Al-Qur'an, Hadits, fiqih, dan sejarah kebudayaan lslam) dengan penekanan pada pembentukan manusia yang hanya menyembah kepada Allah, dan berakhlak mulia (berkarakter baik)

2) Untuk keberhasilan pendidikan karakter diperlukan figur orang tua, guru, pendidik, dan tenaga kependidikan lainnya, serta para pemimpin yang berakhlak mulia.

3) Sistem evaluasi yang seimbang antara aspek kognitif, psikomotor, konasi, dan iman, sehingga lulusan anak didik tidak semata-mata ditentukan oleh hasil ujian nasional yang bersifat kognitif semata, tetapi pelaksanaan ajaran agama dan akhlak mulia juga perlu dikedepankan

2. Saran

Melihat fakta tentang pendidikan di lndonesia yang belum mampu memberikan hasil yang memaskan dari sisi pendidikan karakter, terutama karakter berbasis lslam, maka penulis memberikan saran sebagai berikut :

a. Para pengambil kebijakan yang ada di pusat, daerah, maupun lembaga pendidikan lslam mau menggali, mengkaji, dan mengaplikasikan di satuan pendidikan tentang konsep dan metode 
Nabi Muhammad Sallahu 'Alaihi Wa Sallam, dalam pendidikan karakter.

b. Khusus bagi praktisi pendidikan, pendidik, dan tenaga kependidikan melakukan rekonstruksi, dan reformulasi terhadap pendidikan selama ini, kemudian disesuaikan dengan konsep dan metode Nabi Muhammad Sallahu 'Alaihi Wa Sallam, dalam pendidikan karakter

c. Untuk keberhasilan pendidikan karakter anak bangsa, perlu ditinjau ulang muatan kurikulum yang terlalu banyak dan berat, juga sistem evaluasi ujian nasional.

End Notes

${ }^{1}$ Q.S. Al-Qalam : 4

${ }^{2}$ H.R. Al-Baihaqi dari Abu Hurairah, Sunan Al-kubro Lil Baihaqi 15/252

${ }^{3}$ Komisi Perlindungan Anak lndonesia KPAI, Tahun 2013

${ }^{4}$ Badan Narkotika Nasional (BNN), Tahun 2014

${ }^{5}$ https//m.detik.com/20detik/detkflash/20190829-190829048

${ }^{6}$ Kamus Besar Bahasa lndonesia, h. 740

${ }^{7}$ Abu Namira Hasna Al-Jauziyah, Definisi Manhaj, dalam http//abunamira, wordpress.com/2011/10/19/002-definisi-manhaj/(19 Oktober 2011)

${ }^{8}$ Q.S. Al-Maidah : 48

${ }^{9}$ Muhammad lmarah, Manhaj lslam Cara Berpikir dan Bertindak Sesuai dengan Nilai lslam, terj. Maliatus Zakiyah, Jakarta : Al-Ghuraba, 2008, vii

${ }^{10}$ Q.S. Ali lmran : 164

${ }^{11}$ Q.S. Ali lmran : 110

${ }^{12}$ Abdullah Munir, Pendidikan Karakter Anak Sejak Dari Rumah, Yogyakarta : Pedagogia, 2010, h. 3

${ }^{13}$ Fatchul Mu'in, Pendidikan Karakter Konstruksi Teoritik dan Praktik, Yogyakarta : Aruzz Media, 2011, h. 162

${ }^{14}$ Fariq bin Gasim Anuz, Bengkel Akhlak, Jakarta : Darul Falah, 1423 H./2002, h. 13

${ }^{15}$ Syaikh Khumais as-Sa'id, Beginilah Rasulullah SAW Mengajari Kami, terj. Ali Fauzan dan Muhammad Ashim, Jakarta : Darus Sunnah, 2008, h. 24 
${ }^{16}$ Ahmad Sudrajat, Apa Pendidikan Karakter itu?, dalam http//ahmadsudrajat, wordpress. com/2010/09/15/konsep-pendidikan-karakter/15 September 2010

${ }^{17}$ Ratna Megawati, Pendidikan Karakter Solusi yang Tepat untuk Membangun Bangsa, Bogor : Indonesia Heritage Foundation, 2004, h. 95

${ }^{18}$ Sa'dun Akbar, Revitalisasi Pendidikan Karakter di Sekolah Dasar, Malang : Universitas Malang, 2011, h. 8

${ }^{19}$ Ahmad Sudrajat, Apa Pendidikan Karakter itu?, dalam http//ahmadsudrajat, wordpress. com/ 2010/09/15/konsep-pendidikan-karakter/15 September 2010

${ }^{20}$ M. Mujib Ansor, Pendidikan Karakter Berbasis Sunnah Nabi SAW, Malang : Pustaka Al-Umm, 2013, h. 26

${ }^{21}$ Ahmad Sudrajat, Apa Pendidikan Karakter itu?, dalam http//ahmadsudrajat, wordpress. com/2010/09/15/konsep-pendidikan-karakter/15 September 2010

${ }^{22}$ Doni Koesuma, Pendidikan Karakter Teori dan Praktek di Sekolah, Bandung : PT. Remaja Rosda Karya, h. 9

${ }^{23}$ lbid

${ }^{24}$ lbnu Katsir, Sirah Nabi Muhammad Sallahu 'Alaihi Wa Sallam, terj. Abu lhsan Alatsari, Jakarta : Pustaka Imam asy-Syafi'i, 2010, h. 32

${ }^{25}$ lbid

${ }^{26}$ Surat Al-'Alaq ayat $1-5$

${ }^{27}$ Abudin Nata, Sejarah Pendidikan lslam, Jakarta : Kencana Pranada Media Group, 2011, h. 77

${ }^{28}$ Surat Al-Qalam : 4

${ }^{29}$ Musnad lmam Ahmad, 7/234

${ }^{30}$ Ibnu Katsir, Sirah Nabi Muhammad Sallahu 'Alaihi Wa Sallam, terj. Abu lhsan Alatsari, Jakarta : Pustaka lmam asy-Syafi'i, 2010, h. 349

${ }^{31}$ Abdul Mun'im Al-Hasyimi, Akhlak Rasul Menurut Bukhari dan Muslim, ter. Abdul Hayyie Al-Kattani dan Arif Chasasul Muna, Jakarta : Gema lnsani, 2009, h. 266

${ }^{32}$ H.R. Bukhori dan Muslim, dari Abi Hurairah

${ }^{33}$ Shahih Muslim, (16/137), Sunan at-Tirmudzi (19/76)

${ }^{34}$ Abdul Mun'im Al-Hasyimi, Akhlak Rasul Menurut Bukhari dan Muslim, ter. Abdul Hayyie Al-Kattani dan Arif Chasasul Muna, Jakarta : Gema lnsani, 2009, h. 120

${ }^{35}$ Raghib as-Sirjani, Rasulullah Teladan untuk Semesta Alam, h. 24 
${ }^{36}$ lbid

${ }^{37}$ Q.S. Ali lmran : 134

${ }^{38}$ Abdul Mun'im Al-Hasyimi, Akhlak Rasul Menurut Bukhari dan Muslim, ter. Abdul Hayyie Al-Kattani dan Arif Chasasul Muna, Jakarta : Gema lnsani, 2009, h. 251

${ }^{39}$ Q.S. Al-Anbiya : 107

${ }^{40}$ H.R. Ad-Darimi (15), lbnu Abi Syaibah (275/17)

${ }^{41}$ Akhlak Rasul menurut Bukhari dan Muslim, h. 24

${ }^{42}$ Moh. Slamet Untung, Muhammad Sang Pendidik, h. 89

${ }^{43}$ Awy A. Qalawun, Rasulullah Guru Paling Kreatif, Inovatif, dan Sukses Mengajar, Jogjakarta :Diva Press, 2012, h. 43

${ }^{44 l}$ bid h. 46

${ }^{45}$ Fadhi llahi, Bersama Rasulullah Mendidik Generasi ldaman, terj. Ahmad Yunus, Jakarta : Pustaka lmam Syafi'i, 2010, h. 151

${ }^{46}$ Syaikh Jamal Abdurrahman, lslamic Parenting ..., xvii, mengutip dari kitab lhya' Ulumuddin III/62

${ }^{47}$ Al-Maghribi bin as-Said Al-Maghribi, Begini Seharusnya Mendidik Anak

${ }^{48}$ lbid h. 379

${ }^{49}$ lbid h. 135

${ }^{50}$ Awy A. Qalawun, Rasulullah Guru Paling Kreatif, Inovatif, dan Sukses Mengajar, Jogjakarta :Diva Press, 2012, h. 107

${ }^{51}$ Q.S. Adz-Dzariyat : 55

${ }^{52}$ Al-Maghribi bin as-Said Al-Maghribi, Begini Seharusnya Mendidik Anak

${ }^{53}$ lbid h. 373

${ }^{54}$ Awy A. Qalawun, Rasulullah Guru Paling Kreatif, lnovatif, dan Sukses Mengajar, Jogjakarta :Diva Press, 2012, h. 111

${ }^{55}$ Syaikh Ahmad Farid, Pendidikan Berbasis Metode, ... h. 463

${ }^{56}$ Q.S. Yusuf : 111

${ }^{57}$ Syaikh Manna al-Qaththan, Pengantar Studi llmu Al-Qur'an, h. 386

${ }^{58}$ Awy A. Qalawun, Rasulullah Guru Paling Kreatif, Inovatif, dan Sukses Mengajar, Jogjakarta :Diva Press, 2012, h. 111 
${ }^{59}$ Fadhi llahi, Bersama Rasulullah Mendidik Generasi ldaman, terj. Ahmad Yunus, Jakarta : Pustaka lmam Syafi'i, 2010, h. 141

${ }^{60}$ lbid

${ }^{61}$ Syaikh Ahmad Farid, Pendidikan Berbasis Metode, ... h. 472

${ }^{62}$ Q.S. Ali lmran : 159

${ }^{63}$ Imam an-Nawawi, Riyadh ash-Shalihin, h. 234, hadits nomor 636

${ }^{64}$ Musnad lmam Ahmad, 7/209

${ }^{65}$ Muhammad Nur Abdul Hafizh Suwaid, Prophetic Parenting, Cara Nabi Mendidik Anak, terj. Farid Abdul Aziz Qurusy, Yogyakarta : Pro-U Media, 2010 h. 194

${ }^{66}$ Muhammad Zainul Haq, Muhammad Sebagai Guru, Bantul : Kreasi Wacana, 2010, h. 134

${ }^{67}$ Syaikh Jamal Abdurrahman, lslamic Parenting ..., xvii, h. 156

${ }^{68}$ Saad Riyadh, Jiwa Dalam Bimbingan Rasulullah, h. 22

${ }^{69}$ Masykur Arif Rahman, Kesalahan Kesalahan Fatal Paling Sering Dilakukan Guru dalam Kegiatan Belajar Mengajar, Jogjakarta :Diva Press, 2011, h. 8

${ }^{70}$ lbid h. 16-24

${ }^{71}$ Al-Maghribi bin as-Said Al-Maghribi, Begini Seharusnya Mendidik Anak

${ }^{72}$ Ahmad Dimyati Rosyid, Reaktualisasi Pemikiran lbnu Taimiyah ... h. 118

${ }^{73}$ Konasi merupakan mental insan yang dialami setiap manusia, seperti kemauan, kehendak, hasrat dan niat

${ }^{74}$ lbid h. 117

${ }^{75}$ Munif Chatib, Sekolahnya Manusia Berbasis Multiple lntelligences di Indonesia, Bandung : Kaifa, 2009, h. 71

${ }^{76}$ Ahmad Dimyati Rosyid, Reaktualisasi Pemikiran lbnu Taimiyah ... h. 117

${ }^{77}$ Q.S. At-Taubah : 105

${ }^{78}$ Abdullah Munir, Pendidikan Karakter Anak Sejak Dari Rumah, Yogyakarta : Pedagogia, 2010, h. xi 
